\title{
Parasitoids of Delia planipalpis (Meigen) and Delia platura (Stein) (Diptera, Anthomyiidae) in Mexico
}

\author{
Paulina Nava-Ruiz', Ricardo Meraz-Álvarez², Jorge Valdez-Carrasco², \\ Onésimo Chávez-López ${ }^{3}$, Néstor Bautista-Martínez²
}

I Campo Experimental de Delicias CIRNOC-INIFAP, Km 2 carretera Delicias-Rosales, Delicias C.P. 33000, Chihuahua, México 2 Colegio de Postgraduados, Posgrado en Fitosanidad-Entomología y Acarología, Carretera MéxicoTexcoco Km 36.5, Montecillo, Texcoco 56230, Estado de México, México 3 Iniciativa Privada, Texcoco, México

Corresponding author: Néstor Bautista-Martínez (nestor@colpos.mx)

Academic editor: Andreas Köhler | Received 15 February 2021 | Accepted 9 May 2021 | Published 21 June 2021

http://zoobank.org/6AAD5790-04CB-4603-B435-0E956D910223

Citation: Nava-Ruiz P, Meraz-Álvarez R, Valdez-Carrasco J, Chávez-López O, Bautista-Martínez N (2021) Parasitoids of Delia planipalpis (Meigen) and Delia platura (Stein) (Diptera, Anthomyiidae) in Mexico. ZooKeys 1046: 177-187. https://doi.org/10.3897/zookeys.1046.64405

\begin{abstract}
Among the insect pests that affect crucifer crops in Mexico are Delia planipalpis (Meigen) and D. platura (Stein). They are a threat to the production of these vegetables since the damage they cause directly and indirectly affects yield, quality, and commercialization of these crops. Nevertheless, the existence of natural enemies of these dipterans is still unknown. It is fundamental to determine which parasitoids or predators can be considered possible biological control agents in an integrated pest management program.

The sampling sites were located in Guanajuato, Puebla, and the State of Mexico, where plants of Brassica oleracea L. var. italica Plenk and capitata L., B. napus L., and Raphanus sativus L. infested with Delia spp. were selected. The symptoms observed were wilting, yellowish, flaccid leaves and individuals less developed than the rest of the crop. These plants were extracted with their root and the surrounding soil. Also, wild crucifers were collected, such as Raphanus raphanistrum L., Brassica campestris L., and Sisymbrium irio L. The first records of Aphaereta pallipes Say (Hymenoptera, Braconidae), Trybliographa rapae (Westwood) (Hymenoptera, Figitidae), and Aleochara bimaculata Gravenhorst (Coleoptera, Staphylinidae) are reported parasitizing the puparia of these anthomyiid flies on cultivated and wild crucifers. This represents only a starting point for the continuous study of these parasitoids, which is needed to consider them useful for the biological control of $D$. planipalpis and $D$. platura.
\end{abstract}

\section{Keywords}

Biological control, crucifers, Hymenoptera, root maggots, soil pests, Staphylinidae

Copyright Paulina Nava-Ruiz et al. This is an open access article distributed under the terms of the Creative Commons Attribution License (CC BY 4.0), which permits unrestricted use, distribution, and reproduction in any medium, provided the original author and source are credited. 


\section{Introduction}

Some species of the genus Delia (Robineau-Desvoidy) (Diptera, Anthomyiidae), commonly called root maggots, attack economically important crops of the family Brassicaceae (Brooks 1951; Finch 1989). These insects cause large economic losses to agriculture in temperate regions between latitudes of $30^{\circ} \mathrm{N}$ and $60^{\circ} \mathrm{N}$ (De Wilde 1947; Dixon et al. 2014). One example is the cabbage root fly, Delia radicum L., which is distributed in Europe (Belgium, Denmark, and Spain), North America (Canada and the United States), Asia (China, Turkey, and Israel), and Africa (Algeria and Morocco) (CABI 2021). It is one of the most difficult agricultural pests to control, causing losses in rapeseed of up to $50.0 \%$ (Finch 1989; Dosdall et al. 1994). Another related dipteran reported as a crucifer pest is $D$. planipalpis (Meigen), sister species of $D$. radicum and D. floralis (Fallén) (Dixon et al. 2014), whose main host is radish (Raphanus sativus L.) (Brooks 1951; Kelleher 1958). However, it has also been observed attacking commercial broccoli (Brassica oleracea L. var. italica Plenck), cabbage (B. oleracea var. capitata L.), cauliflower (B. oleracea var. botrytis L.), radish, turnip (B. napus L.), and wild crucifers such as field mustard (B. campestris L.), wild radish ( $R$. raphanistrum L.), and London rocket (Sisymbrium irio L.) (Meraz-Álvarez et al. 2020). Nevertheless, most of studies have focused mainly on $D$. radicum and, to a lesser degree, on the onion fly (D. antiqua (Meigen)) (Finch 1989; Hemachandra et al. 2007). There are other species that are mainly saprophagous, such as D. florilega (Zetterdest) and D. platura (Stein), which have a wider range of hosts and can feed on decomposing tissue. However, under certain circumstances, they also feed on healthy tissues of plants of the family Brassicaceae and species of the genus Allium L., as well as legumes, Cucurbitaceae, and cereals (Griffiths 1993; Howard et al. 1994; Meraz-Álvarez et al. 2020).

Currently, there are few precedents of D. planipalpis and D. platura associated with crucifers in Mexico. Larvae of these dipterans cause damage mainly to the root crown of some cultivars of $B$. oleracea, and consequently, they affect the root system. Occasionally, the larvae develop near the broccoli head causing rot and malformation, or no formation of the inflorescence. In addition, in crops such as radish and turnip, direct damage caused by larvae to their edible part makes their commercialization difficult (Meraz-Álvarez et al. 2020). The presence of D. planipalpis and D. platura constitutes potential risk for production of this type of vegetable in Mexico, which in 2019 earned 1.113 billion dollars from export of broccoli, cabbage, and cauliflower, making Mexico the fourth largest producer worldwide (SIAP 2020). The production chain up to the end consumer requires much labor. Broccoli uses 76 workdays per season, compared with maize (the most cultivated crop in Mexico), which uses 17.25 workdays (Maldonado-Montalvo et al. 2017).

Because more than $60 \%$ of these crucifers are exported to international markets, compliance with strict sanitation, quality, and food safety regulation is required. These restrictions make it obligatory to use chemical control as one of the most common tactics for pest control (Bujanos et al. 2013). However, misuse of pesticides can lead to emergence of resistant populations, health problems for appliers, destruction of 
non-target arthropods (Pimentel et al. 1993; Lagunes-Tejeda et al. 2009), and residual pesticides in concentrations that are not acceptable in the destination countries, among other problems, and consequently, to loss of important markets. In this respect, $D$. radicum has developed resistance to chlorpyrifos in some areas where rutabaga (B. napus var. napobrassica (L.)) is grown in Canada (Blackshaw et al. 2012), and high concentrations of pesticide residues pollute aquifers (Joseph and Zarate 2015). In December 2007, the European Union banned chlorfenviphos, which was used to control D. radicum (Ferry et al. 2009); this, together with other restrictions that are being promoted in European countries to protect the environment and human health, presents another challenge for crucifer growers (Collier et al. 2020).

In addition, larvae of Delia are difficult to control because they are found in the soil or inside plant tissues, where it is difficult for sprayed insecticides to reach. For this reason, it is essential to identify natural enemies of these dipterans in crucifer-producing regions and contribute management options that use them as potential biological control agents. In this sense, the objective of this study was to search for and identify parasitoid insects and/or predators of D. planipalpis and D. platura in cultivated and wild crucifers.

\section{Methods}

The study was conducted between February 2018 and February 2019 in Guanajuato, Puebla, and the State of Mexico, where some sites infested by Delia spp. were located (Table 1). The crops included in the collections were broccoli (Brassica oleracea var. italica Plenck), cabbage (B. oleracea var. capitata L.), turnip (B. napus L.), radish (Raphanus sativus L.), and other wild crucifers such as field mustard (B. campestris L.), London rocket (Sisymbrium irio L.), and wild radish ( $R$. raphanistrum L.).

Sampling was directed; 10 plants per site were selected, considering those that were observed to be stressed by water deficit and having wilting, yellowish, flaccid leaves and/or less vegetative development than the rest of the crop; these are characteristic symptoms of infestation by Delia spp. Wild crucifer plants were selected at random within and on the outer edges of commercial crops and the sample size varied from 5 to 10 plants depending on their abundance. Each plant was extracted with its root and adhered soil and placed in a polyethylene bag; additionally, with a post hole digger of $15.0 \mathrm{~cm}$ in diameter by $20.0 \mathrm{~cm}$ long, the soil of the first $10.0 \mathrm{~cm}$ of depth was collected taking as a reference point the exact site where the plant was extracted and because in this place the puparia are distributed due to the limited movement of third instar larvae around the plant and from the soil surface (Abu 1960). This soil was placed together with its respective plant in the polyethylene bag, which was labeled with the collection data.

The collected material was taken to the Entomology Laboratory at the Colegio de Postgraduados Campus Montecillo, Texcoco, Mexico, where the puparia and larvae were separated from the soil. A sieve with $2.0-2.8 \mathrm{~mm}$ openings was used to sift the 
Table I. Collection sites of samples infested by Delia planipalpis and D. platura.

\begin{tabular}{|c|c|c|}
\hline \multirow[t]{2}{*}{ Host } & \multicolumn{2}{|c|}{ Site } \\
\hline & Location & Date \\
\hline R. raphanistrum & Colegio de Postgraduados Campus & 19-II-2018 \\
\hline S. irio & Montecillo, Texcoco, State of México & 29-III-2018 \\
\hline R. sativus & $19^{\circ} 28^{\prime} 08.2^{\prime \prime N}, 98^{\circ} 54^{\prime} 04.7 " \mathrm{~W}$ & $19-\mathrm{V}-2018$ \\
\hline R. raphanistrum & & $20-\mathrm{X}-2018$ \\
\hline B. campestris & & 19-XI-2018 \\
\hline B. oleracea var italica & $\begin{array}{c}\text { San Diego de La Unión, Guanajuato } \\
21^{\circ} 24^{\prime} 30.4^{\prime \prime N}, 100^{\circ} 45^{\prime} 19.3^{\prime \prime W}\end{array}$ & $\begin{array}{c}25-\mathrm{X}-2018 \\
04-\mathrm{XII}-2018\end{array}$ \\
\hline B. napus & San Felipe Tenextepec, Tepeaca, Puebla & 04-IV-2018 \\
\hline B. oleracea var capitata & $18^{\circ} 57^{\prime} 27.18^{\prime \prime N}, 97^{\circ} 50^{\prime} 50.24 " \mathrm{~W}$ & 21-IX-2018 \\
\hline R. raphanistrum & & 08-XI-2018 \\
\hline B. oleracea var italica & & 08-XI-2018 \\
\hline R. raphanistrum & Los Reyes, Tepeaca, Puebla & 22-XI-2018 \\
\hline R. sativus & $19^{\circ} 00^{\prime} 01.1 " \mathrm{~N}, 97^{\circ} 53^{\prime} 14.4^{\prime \prime} \mathrm{W}$ & 22-XI-2018 \\
\hline B. oleracea var capitata & & 22-XI-2018 \\
\hline R. sativus & Guadalupe Calderón, Tepeaca, Puebla & 06-XII-2018 \\
\hline R. raphanistrum & $18^{\circ} 57^{\prime} 41.86^{\prime \prime N}, 97^{\circ} 50^{\prime} 32.44^{\prime \prime W}$ & 06-XII-2018 \\
\hline B. oleracea var italica & San Diego, Texcoco, State of México & 22-II-2019 \\
\hline B. oleracea var capitata & $19^{\circ} 30^{\prime} 09.8^{\prime \prime N}, 98^{\circ} 51^{\prime} 33.1 " \mathrm{~W}$ & 22-II-2019 \\
\hline & & 22-II-2019 \\
\hline
\end{tabular}

soil and remove the Delia spp. larvae and puparia. To separate the larvae from damaged tissues, small cuts were made on the root and stem of the plants to search for galleries resulting from their feeding. These tissues were observed with an American Optical Model 570 stereoscopic microscope. The larvae obtained were placed in plastic $12.0 \mathrm{~cm}$ Petri dishes conditioned with moistened paper at the bottom on which two to three slices of radish were placed to provide them with food. In this way, they continued their development until reaching the pupal stage. The puparia obtained from sifting soil and those that resulted from collected larvae were observed under a microscope to separate $D$. planipalpis from $D$. platura using illustrations of Savage et al. (2016) as reference. The puparia were placed individually in $5.0 \mathrm{~cm}$ Petri dishes conditioned with moistened paper on the bottom and labeled with their collection data. This material was maintained in a rearing chamber at $26 \pm 2{ }^{\circ} \mathrm{C}, 60 \pm 10 \%$ relative humidity, and with a photoperiod of 12:12 (light: dark). Emergence of $D$. planipalpis, D. platura, and parasitoids was recorded daily. The emerged insects were collected, preserved in $70 \%$ alcohol in glass vials, and labeled with their respective data for later identification.

The keys of Campos and Sharkey (2006), Berry (2007), Forshage and Nordlander (2008), Quinlan (1978), and Nordlander (1981) were used to identify the parasitoids. Specimens were also sent for corroboration to the following specialists: Dr Juana María Coronado Blanco (Universidad Autónoma de Tamaulipas, specialist in the family Braconidae), Dr Fabiana Gallardo (School of Natural Sciences and Museum in Buenos Aires, Argentina, specialist in the family Figitidae), and Dr José Luis Navarrete Heredia (Universidad Autónoma de Guadalajara). The material is kept as reference specimens in the entomological collection of the Colegio de Postgraduados Campus Montecillo. 
Table 2. Parasitoids emerged from Delia planipalpis and D. platura puparia collected in commercial crops and weeds.

\begin{tabular}{|c|c|c|c|c|c|c|c|c|}
\hline \multicolumn{2}{|c|}{ Number of puparia collected } & \multicolumn{6}{|c|}{ Emerged parasitoids } & \multirow[t]{3}{*}{ Host } \\
\hline \multirow[t]{2}{*}{ D. planipalpis } & \multirow[t]{2}{*}{ D. platura } & \multicolumn{2}{|c|}{ Aphaereta pallipes } & \multicolumn{2}{|c|}{ Trybliographa rapae } & \multicolumn{2}{|c|}{ Aleochara bimaculata } & \\
\hline & & 우우 & $\hat{0} \sigma^{\lambda}$ & 우우 & के & 우우 & $\hat{o ̂ o}^{2}$ & \\
\hline 0 & 20 & 0 & 0 & 2 & 1 & 0 & 0 & R. raphanistrum \\
\hline 0 & 14 & 0 & 0 & 2 & 11 & 0 & 0 & $R$ sativus \\
\hline 11 & 2 & 0 & 0 & 0 & 0 & 1 & 0 & B. oleracea var italica \\
\hline 18 & 0 & 7 & 4 & 0 & 0 & 0 & 0 & \\
\hline 13 & 0 & 6 & 3 & 0 & 0 & 2 & 2 & B. oleracea var capitata \\
\hline 57 & 8 & 56 & 15 & 0 & 0 & 0 & 0 & R. raphanistrum \\
\hline 13 & 0 & 29 & 10 & 0 & 0 & 0 & 0 & B. oleracea var italica \\
\hline 44 & 1 & 13 & 1 & 0 & 0 & 0 & 0 & R. raphanistrum \\
\hline 34 & 2 & 22 & 7 & 0 & 0 & 0 & 0 & R. sativus \\
\hline 53 & 2 & 29 & 19 & 0 & 0 & 0 & 0 & R. sativus \\
\hline 44 & 0 & 93 & 39 & 0 & 0 & 0 & 0 & R. raphanistrum \\
\hline
\end{tabular}

\section{Results}

A total of 321 Delia planipalpis and 49 D. platura puparia were collected in cultivated and wild crucifers in the states of Guanajuato, Puebla, and the State of Mexico (Table 2). From these puparia, three parasitoids emerged: Aphaereta pallipes Say (Hymenoptera, Braconidae), Trybliographa rapae (Westwood) (Hymenoptera, Figitidae), and Aleochara bimaculata Gravenhorst (Coleoptera, Staphylinidae) (Fig. 1). Of these three species, only in $A$. pallipes was gregarious habit observed, with up to 15 individuals obtained per $D$. planipalpis puparium.

Aphaeretha pallipes emerged from puparia of $D$. planipalpis reared on $B$. oleracea var. italica, $B$. oleracea var. capitata, $R$. sativus, and $R$. raphanistrum from samples collected in Guanajuato and Puebla, A. bimaculata emerged from puparia of D. planipalpis and $D$. platura reared on B. oleracea var. italica and capitata from these places, and $T$. rapae emerged from puparia of $D$. platura reared on samples of $R$. sativus and $R$. raphanistrum from the State of Mexico.

\section{Discussion}

The frequency of Aphaereta pallipes observed in the collected samples was $90 \%$. In contrast, Aleochara bimaculata was present in $20 \%$ of the samples; likewise, the appearance of Trybliographa rapae was also minimal. Thus, $A$. pallipes is the most common parasitoid of Delia planipalpis in Guanajuato and Puebla.

Our findings contrast with what has been reported by other authors, who stated that Aleochara bilineata and T. rapae are the most common parasitoids of several root maggot species, including D. planipalpis and D. platura in Europe and Canada (Wilkes and Wishart 1953; Wishart 1957; Hemachandra et al. 2007), and T. rapae is capable of parasitizing up to $45 \%$ of their hosts (Wishart and Montheith 1954). In similar studies, additional species such as Aphaereta difficilis Nees, A. tennuicornis Nixon (Wishart et al. 


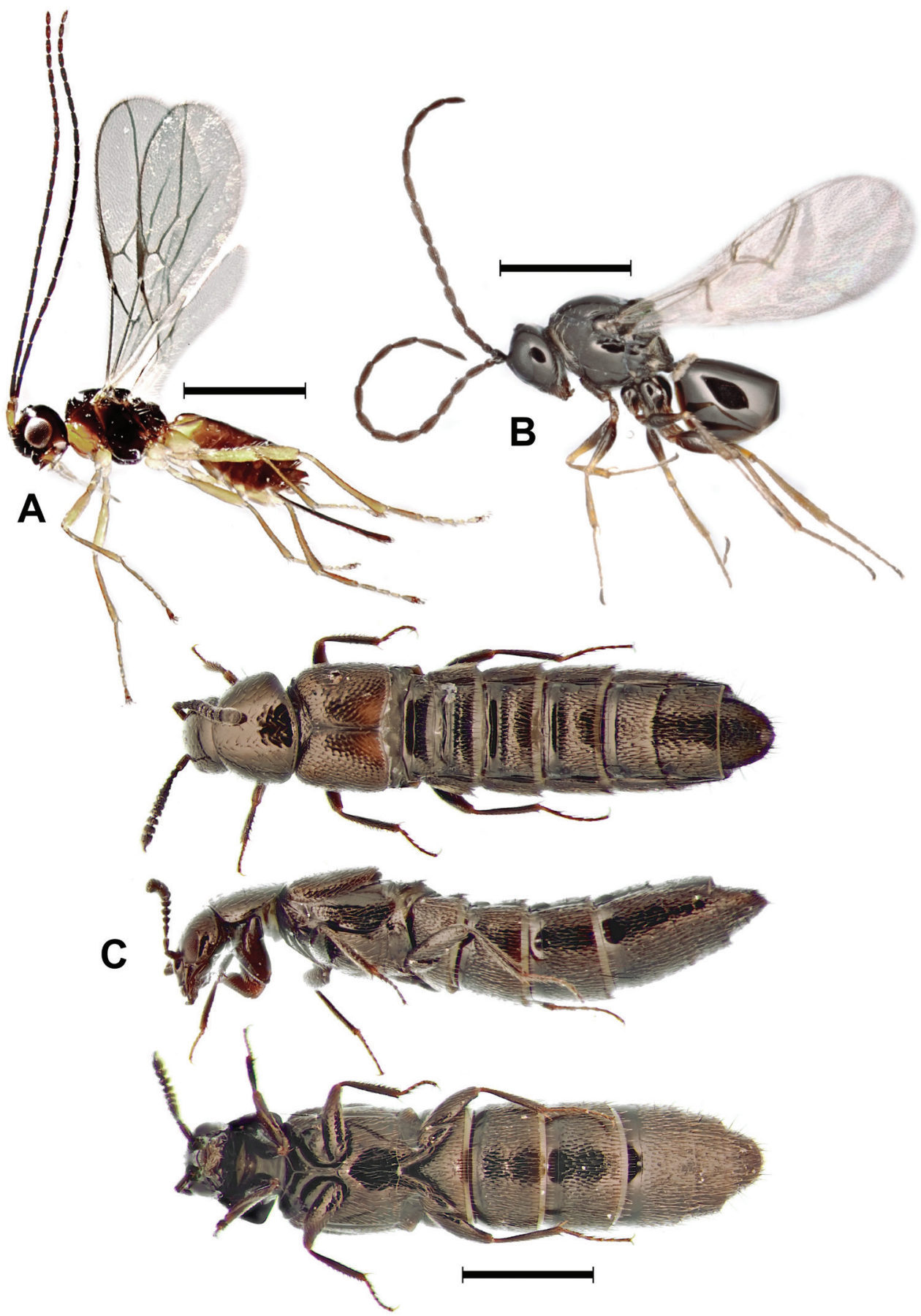

Figure I. A Aphaereta pallipes (Say) (Hymenoptera: Braconidae) B Trybliographa rapae (Westwood) (Hymenoptera: Figitidae) C Aleochara bimaculata Gravenhorst (Coleoptera: Staphylinidae). Scale bars: $1 \mathrm{~mm}$. 
1957), A. auripes (Provancher) (Wishart 1957), and the staphylinides Aleochara bipustulata and A. verna (Hemachandra et al. 2007) are named as occasional parasitoids of Delia spp. However, except for the presence of T. rapae, the species differ from our report.

Although $A$. pallipes has not been mentioned as an important parasitoid of Delia spp. in Europe and Canada, Tomlin et al. (1985) reported that $A$. pallipes and A. bilineata caused mortalities of up to 17 and $20 \%$, respectively, in D. antiqua in commercial onion crops in southwestern Ontario. This braconid has a wide range of hosts and prefers members of at least three families, Coelophidae, Calliphoridae and Anthomyiidae (Wharton 1984), but it has also been reported in Sarcophagidae and Muscidae (Figg et al. 1983); therefore, the relative scarcity of $A$. pallipes may be due to its host preferences (Wilkes and Wishart 1953). Importantly, the presence of certain species and their percentages of parasitism are highly variable, depending on the crop, type of soil, geographic location (Wishart 1957), climate, host density (Jones and Hassell 1988; Turnock et al. 1995), differences in agronomic practices, habitat ecology of each crop, and even the number of host generations during the year (Nair and McEwen 1975).

In the case of $A$. bimaculata, our results are apparently different from those reported by other researchers in that most studies mention that $A$. bimaculata has been found parasitizing dipterans that develop in manure. Klimaszewski (1984) mentioned that A. bimaculata can be used as a biological control agent of some muscids, such as horn fly, Haematobia irritans L., and face fly, Musca autumnalis De Geer (Diptera, Muscidae). In addition, it has been reported that this staphylinid also attacks Adia cinerella Fallen (Diptera, Anthomyiidae) and Scatophaga stercolaria L. (Diptera, Scatophagidae) (Cervenka and Moon 1991), as well as Musca domestica L. (Diptera, Muscidae) (Wingo et al. 1967). Even though these are not insects of agricultural importance, the families to which they belong are closely related (Ding et al. 2015; Kutty et al. 2019). A. bimaculata has a Nearctic and Neotropical distribution (Maus et al. 1998) and that it is found in some regions of Mexico such as Guanajuato and Puebla (NavarreteHeredia et al. 2002), it is expected and normal to find A. bimaculata parasitizing Delia spp. pupae in crucifer crops since species of Aleochara generally live in habitats where larvae of Cyclorrhapha dipterans develop (Maus et al. 1998).

Finally, although in this work no parasitoids were found in the wild crucifers B. campestris and S. irio, alternate hosts are important reservoirs of considerable populations of Delia spp. and consequently of their natural enemies, especially because they provide habitat during the season when there are no crops. In this way, wild crucifers assure that there is no scarcity of hosts for either the insect pest or their parasitoids and predators (Johnsen and Gutierrez 1997; Hemachandra 2007).

\section{Conclusions}

Three species that emerged from puparia of $D$. planipalpis and $D$. platura collected in cultivated and wild crucifers were identified: one gregarious parasitoid, 
Aphaereta pallipes and two solitary parasitoids, Trybliographa rapae and Aleochara bimaculata. Only Aphaereta pallipes and T. rapae were specific to D. planipalpis and D. platura, respectively. Finally, A. bimaculata was associated with both pest species.

This is the first record of parasitoids of $D$. planipalpis and D. platura that occur naturally in Mexico. Aphaereta pallipes was the most abundant species, found in Guanajuato and Puebla, followed by Aleochara bimaculata, and finally T. rapae, which was found only in the State of Mexico. Knowledge of natural enemies of Delia spp. in crucifer-producing regions is only the starting point from which to broaden the search and begin to study their biological attributes with the aim of incorporating them into a biological control program against $D$. planipalpis and D. platura.

\section{References}

Abu YIK (1960) Natural control in cabbage root fly populations and influence of chemicals. Mededelingen van de Landbouwhogeschool te Wageningen Nederland 60: 1-57.

Blackshaw RP, Vernon RS, Prasad R (2012) Reduction of Delia radicum attack in field brassicas using a vertical barrier. Entomologia Experimentalis et Applicata 144: 145-156. https:// doi.org/10.1111/j.1570-7458.2012.01271.x

Brooks AR (1951) Identification of the Root Maggots (Diptera: Anthomyiidae) Attacking cruciferous garden crops in Canada, with notes on biology and control. The Canadian Entomologist 83: 109-120. https://doi.org/10.4039/Ent83109-5

Berry JA (2007) Alysiinae (Insecta: Hymenoptera: Braconidae). Fauna of New Zealand 58: 1-95. Bujanos MR, Marín JA, Díaz ELF, Herrera VR (2013) Control de plagas del cultivo de brócoli en la región del Bajío, México: El cuadro básico de recomendación de insecticidas. Folleto Técnico No. 26. SAGARPA, INIFAP, Centro de Investigación Regional Centro. Campo Experimental Bajío, 26 pp.

CABI (2021) Delia radicum (cabbage root fly). Invasive Species Compendium. CAB International, Wallingford. http://www.cabi.org/isc [Accessed on 29.01.2021]

Campos DF, Sharkey F (2006) Familia Braconidae. In: Fernandez F, Sharkey MJ (Eds) Introducción a los Hymenoptera de la Región Neotropical. Sociedad Colombiana de Entomología y Universidad Nacional de Colombia, Bogotá, 331-346.

Cervenka VJ, Moon RD (1991) Arthropods associated with fresh cattle dung pats in Minnesota. Journal of the Kansas Entomological Society 64: 131-145. https://www.jstor.org/ stable/25085262

Collier R, Mazzi D, Folkedal Schjøll A, Schorpp Q, Thöming G, Johansen TJ, Meadow R, Meyling NV, Cortesero AM, Vogler U, Gaffney MT, Hommes M (2020) The potential for decision support tools to improve the management of root-feeding fly pests of vegetables in Western Europe. Insects 11: e369. https://doi.org/10.3390/insects11060369

Ding S, Li X, Wang N, Cameron SL, Mao M, Wang Y, Xi Y, Yang D (2015) The phylogeny and evolutionary timescale of Muscoidea (Diptera: Brachycera: Calyptratae) inferred from mitochondrial genomes. PLoS ONE 10: e0134170. https://doi.org/10.1371/journal. pone. 0134170 
Dosdall LM, Herbut MJ, Cowle NT (1994) Susceptibilities of species and cultivars of canola and mustard to infestation by root maggots (Delia spp.) (Diptera: Anthomyiidae). The Canadian Entomologist 126: 251-260. https://doi.org/10.4039/Ent126251-2

De Wilde J (1947) Onderzoek betreffende de koolvlieg en zijn bestrijding (Investigations on the cabbage root maggot, Chortophila brassicae Bché, and its control). Verslag Landbouwk Onderz 53: 309-426.

Dixon P, Cass L, Vincent C, Olfert O (2014) Implementation and adoption of integrated pest management in Canada: Insects. In: Peshin R, Pimentel D (Eds) Integrated Pest Management: Experiences with Implementation. Springer, Dordrecht, 221-252. https://doi. org/10.1007/978-94-007-7802-3_9

Ferry A, Le Tron S, Dugravot S, Cortesero AM (2009) Field evaluation of the combined deterrent and attractive effects of dimethyl disulfide on Delia radicum and its natural enemies. Biological Control 49: 219-226. https://doi.org/10.1016/j.biocontrol.2009.01.013

Figg DE, Hall RD, Thomas GD (1983) Host range and eclosion success of the parasite Aphaereta pallipes (Hymenoptera: Braconidae) among dung-breeding Diptera in Central Missouri. Environmental Entomology 12: 993-995. https://doi.org/10.1093/ee/12.3.993

Finch S (1989) Ecological considerations in the management of Delia pest species in vegetable crops. Annual Review of Entomology 34: 117-137. https://doi.org/10.1146/annurev. en.34.010189.001001

Forshage M, Nordlander G (2008) Identification key to European genera of Eucoilinae (Hymenoptera, Cynipoidea, Figitidae). Insect Systematics and Evolution 39: 341-359. https:// doi.org/10.1163/187631208794760885

Griffiths GCD (1993) Anthomyiidae [part]. Flies of the Nearctic Region 8[2], 10. Edited by GCD Griffiths. E. Schweizerbart, Stuttgart, 1417-1632.

Hemachandra KS, Holliday NJ, Mason PG, Soroka JJ, Kuhlmann U (2007) Comparative assessment of the parasitoid community of Delia radicum in the Canadian prairies and Europe: a search for classical biological agents. Biological Control 43: 85-94. https://doi. org/10.1016/j.biocontrol.2007.07.005

Howard R, Garland JA, Seaman WL (1994) Disease and pests of vegetable crops in Canada. An illustrated compendium. The Canadian Phytopathological Society and the Entomological Society of Canada, Ottawa, 1021 pp.

Johnsen S, Gutierrez AP (1997) Induction and termination of winter diapause in a Californian strain of the cabbage maggot (Diptera: Anthomyiidae). Environmental Entomology 26: 84-90. https://doi.org/10.1093/ee/26.1.84

Jones TH, Hassell MP (1988) Patterns of parasitism by Trybliographa rapae, a cynipid parasitoid of the cabbage root fly, under laboratory and field conditions. Ecological Entomology 13: 309-317. https://doi.org/10.1111/j.1365-2311.1988.tb00361.x

Joseph SV, Zarate J (2015) Comparing efficacy of insecticides against cabbage maggot (Diptera: Anthomyiidae) in the laboratory. Crop Protection 77: 148-156. https://doi.org/10.1016/j. cropro.2015.07.022

Kelleher JS (1958) Life-history and ecology of Hylemya planipalpis (Stein) (Diptera: Anthomyiidae), a root maggot attacking radish in Manitoba. The Canadian Entomologist 90: 675-680. https://doi.org/10.4039/Ent90675-11 
Klimaszewski J (1984) A revision of the genus Aleochara Gravenhorst of America North of Mexico (Coleoptera: Staphylinidae, Aleocharinae). Memoirs of the Entomological Society of Canada 116: 3-211. https://doi.org/10.4039/entm116129fv

Kutty SN, Meusemannb K, Baylesse KM, Marinho MAT, Pont AC, Zhou X, Misof B, Wiegmann BM, Yeates D, Cerretti P, Meier R, Pape T (2019) Phylogenomic analysis of Calyptratae: resolving the phylogenetic relationships within a major radiation of Diptera. Cladistics 35: 605-622. https://doi.org/10.1111/cla.12375

Lagunes-Tejeda A, Rodríguez-Maciel JC, De Loera-Barocio JC (2009) Susceptibilidad a insecticidas en poblaciones de artrópodos de México. Agrociencia 43: 173-196.

Maldonado-Montalvo J, Ramírez-Juárez J, Méndez-Espinoza JA, Pérez-Ramírez N (2017) El sistema de producción del brócoli desde la perspectiva del campo social de Pierre Bourdieu. Estudios sociales 27: 1-20. https://doi.org/10.24836/es.v27i50.487

Meraz-Álvarez R, Bautista-Martínez N, Illescas-Riquelme CP, González-Hernández H, ValdezCarrasco JM, Savage J (2020) Identification of Delia spp. (Robineau-Desvoidy) (Diptera, Anthomyiidae) and its cruciferous hosts in Mexico. ZooKeys 964: 127-141. https://doi. org/10.3897/zookeys.964.53947

Maus C, Mittmann B, Peschke K (1998) Host records of parasitoid Aleochara Gravenhorst species (Coleoptera, Staphylinidae) attacking puparia of cyclorrhapheous diptera. Deutsche Entomologische Zeitschrift 45: 231-254. https://doi.org/10.1002/mmnd.19980450209

Nair KSS, McEwen FL (1975) Ecology of the cabbage maggot, Hylemya brassicae (Diptera: Anthomyiidae) in rutabaga in southwestern Ontario, with some observations on other root maggots. The Canadian Entomologist 107: 343-354. https://doi.org/10.4039/ Ent107343-4

Navarrete-Heredia JL, Newton AF, Thayer MK, Ashe JS, Chandler DS (2002) Guía ilustrada para los géneros de Staphylinidae (Coleoptera) de México. Universidad de Guadalajara. Centro Universitario de Ciencias Biológicas y Agropecuarias (CUCBA). Comisión Nacional para el uso de la Biodiversidad (CONABIO), México, 401 pp.

Nordlander G (1981) A review of the genus Trybliographa Föster, 1869 (Hymenoptera, Cynipoidea: Eucoilinae). Entomologia Scandinavica 12: 381-402. https://doi. org/10.1163/187631281X00454

Pimentel D, Acquay H, Biltonen M, Rice P, Silva M, Nelson J, Lipner V, Giordano S, Horowitz A, D'amore M (1993) Assessment of environmental and economic impacts of pesticide use. In: Pimentel D, Lehman H (Eds) The Pesticide Question. Chapman \& Hall, New York, 47-84. https://doi.org/10.1007/978-0-585-36973-0_3

Quinlan J (1978) Hymenoptera Cynipoidea: Eucoilidae. In: Watson A (Ed.) Handbooks for the Identification of British Insects (Vol. III, Part 1b). Royal Entomological Society of London, London, 58 pp.

Savage J, Fortier AM, Fournier F, Bellavance V (2016) Identification of Delia pest species (Diptera: Anthomyiidae) in cultivated crucifers and other vegetable crops in Canada. Canadian Journal of Arthropod Identification 29: 1-40. https://doi.org/10.3752/cjai.2016.29

SIAP (2020) Panorama agroalimentario. Servicio de Información Agroalimentaria y Pesquera (SIAP). Secretaría de Agricultura y Desarrollo Rural, México, 214 pp. 
Tomlin A, Miller J, Harris C, Tolman J (1985) Arthropod parasitoids and predators of the onion maggot (Diptera: Anthomyiidae) in southwestern Ontario. Journal of Economic Entomology 781: 975-981. https://doi.org/10.1093/jee/78.4.975

Turnock WJ, Boivin G, Whistlecraft JW (1995) Parasitism of overwintering puparia of the cabbage maggot, Delia radicum (L.) (Diptera: Anthomyiidae), in relation to host density and weather factors. The Canadian Entomologist 127: 535-542. https://doi.org/10.4039/ Ent $127535-4$

Wharton RA (1984) Biology of the Alysiini (Hymenoptera: Braconidae), parasitoids of cyclorrhaphous Diptera. Texas Agricultural Experiment Station. Technical Monograph No. 11: $39 \mathrm{pp}$.

Wilkes A, Wishart G (1953) Studies on parasites of root maggots (Hylemya spp.; Diptera: Anthomyiidae) in the Netherlands in relation to their control in Canada. Tijdschrift Over Plantenziekten 59: 185-188. https://doi.org/10.1007/BF01988192

Wingo CW, Thomas GD, Nelms NM (1967) Laboratory evaluation of two aleocharine parasites of the face fly. Journal of Economic Entomology 60: 1514-1517. https://doi. org/10.1093/jee/60.6.1514

Wishart G (1957) Surveys of parasites of Hylemya spp. (Diptera: Anthomyiidae) that attack cruciferous crops in Canada. The Canadian Entomologist 89: 450-454. https://doi. org/10.4039/Ent89450-10

Wishart G, Monteith E (1954) Trybliographa rapae (Westw.) (Hymenoptera: Cynipidae), a parasite of Hylemya spp (Diptera: Anthomyiidae). The Canadian Entomologist 86: 145-154. https://doi.org/10.4039/Ent86145-4

Wishart G, Colhoun EH, Monteith AE (1957) Parasites of Hylemya spp. (Diptera: Anthomyiidae) that attack cruciferous crops in Europe. The Canadian Entomologist 89: 510-517. https://doi.org/10.4039/Ent89510-11 